\title{
Creativity and Innovation as Strategic Resources in International Business Markets*
}

\author{
Maria Rosaria Marcone \\ Polytechnic University of Marches, Ancona, Italy
}

\begin{abstract}
This study focuses on Medium-Sized Multinationals (MSMs) that belong to the sectors of mechanics and electronics, and that operate in dynamic international business markets. This work aims to investigate how international marketing strategies are based and maybe in some cases actually heavily dependent on the capacity to form and enhance skills in design, engineering, and production activities, and on the propensity to invest more resources in research and development $(\mathrm{R} \& \mathrm{D})$ activities as well as in activities that are more strictly speaking production based (manufacturing). Undoubtedly, in a global and dynamic business, creative knowledge is one of the key resources that firms must possess in order to take up international strategies successfully. Creativity and innovation are strategic resources for all firms, including those of a medium size and even more for those that belong to the so-called "traditional sectors". This study also has the objective of examining the influence of the structure and composition of a technological MSMs international alliance portfolio in order to understand which forms of international collaboration are more opportunities for firms that aspire to increasing their know-how and taking up new and more sophisticated forms of exploratory innovation. The present work highlights the results of an empirical research that were carried out during the years 2000-2009. The research involved more than 80 firms of the mechanical and electronics department in the Marche region in Italy.
\end{abstract}

Keywords: technological assets, international business markets, international knowledge flows

\section{Introduction}

This study focuses on Medium-Sized Multinationals (MSMs) that belong to the sectors of mechanics and electronics, and that operate in dynamic international business markets.

This work aims to investigate how international marketing strategies are based and maybe in some cases actually heavily dependent on the capacity to form and enhance skills in design, engineering, and production activities, and on the propensity to invest more resources in research and development (R\&D) activities as well as in activities that are more strictly speaking production based (manufacturing).

Undoubtedly, in a global and dynamic business, creative knowledge is one of the key resources that firms must possess in order to take up international strategies successfully (Kogut \& Zander, 1992; Grant, 1996; Conner \& Prahalad, 1996; Doz \& Hamel, 1998; Nickerson \& Zenger, 2004; Lavie \& Miller, 2008). Creativity

\footnotetext{
* A previous version of the paper has been presented at the International Symposium "The Economic Crisis: Time for a Paradigm Shift. Toward a Systematic Approach”, València University, Spain, January 24-25, 2013.

Maria Rosaria Marcone, Associate Professor, Department of Management, Polytechnic University of Marches.

Correspondence concerning this article should be addressed to Maria Rosaria Marcone, Department of Management, Polytechnic University of Marches, P.le Martelli, 8, 60121, Ancona, Italy. E-mail: m.r.marcone@univpm.it.
} 
and innovation are strategic resources for all firms, including those of a medium size and even more for those that belong to the so-called "traditional sectors".

Within this framework it is managerial ability (Penrose, 1959; Kelly, 2009) that makes a difference in determining the quality of the process of technological knowledge absorption, much more than the entity of the resources invested in R\&D activities.

The present work also highlights how in the current business environment, that is characterized by growing complexity and triggered by hyper-competition and globalization (Knight, 2000), entrepreneurial behaviour finds fertile ground. The field of international entrepreneurship has so far focused on the speed of the firm in adapting to the international market. International entrepreneurial firms are considered to be those smaller firms that from the inception go abroad (Oviatt \& McDougall, 2005; Keupp \& Gassmann, 2009).

In order to capture the entrepreneurial orientation of internationalised MSMs in this research has been noted that entrepreneurial orientation depends on the attitude towards risk-taking, being proactive in relation to opportunities and autonomy, and demonstrating a will to compete in an aggressive manner.

This study also has the objective of examining the influence of the structure and composition of a technological MSM's international alliance portfolio in order to understand which forms of international collaboration are more opportunities for firms that aspire to increasing their know-how and taking up new and more sophisticated forms of exploratory innovation (Johanson \& Vahlne, 1990; Wright, Westhead, \& Ucbasaran, 2007; Wincent, Örtqvist, Eriksson, \& Autio, 2010).

Recent globalization and increased competition have forced firms to re-evaluate their current configuration and location activities. Recognition of knowledge sources that are far more spread around the globe has induced firms to re-think their configuration of knowledge-based activities, such as manufacturing and R\&D.

The paper also seeks to analyse the way in which the transfer of knowledge takes place between elements of the same company that has localized production and research activities in different foreign markets. More and more often we can see that the complex process of knowledge transfer occurs as a part of strategic alliances that involve medium firms and big multinationals and research institutions.

The training and the acquisition of the most advanced technological knowledge by medium enterprises are deeply connected to their ability to improve internal managerial skills, integrating them with those present on a global scale in the firms of the competition, in the firms of the partners, and even in the firms abroad that have the same ownership.

Technological knowledge, that external subject (enterprises, universities, research structures, etc.) mature and incorporate in terms of services and products offered, is an indispensable resource for MSMs that pursue the growth of their technological legacy with continuity and aspire towards the accumulation of a modern managerial culture aimed at knowledge management.

As far as the methodology adopted in the development of the research is concerned, both inductive and deductive methodologies are used, principally adopting a "positive-interpretative" approach. In contrast to many extant studies of MSMs, both survey and objectively measured data are combined, and because the secondary data collected contain both resource-level (input) data and subsequent one-year financial data, a higher level of confidence may be attributable to our findings.

The present work highlights the results of my empirical research that was carried out during the years 2000-2009. The research involved more than 80 firms of the mechanical and electronics department in the Marche region in Italy. The study is particularly based on the empirical analysis of the most representative 
business cases among those analysed in the mechanical and electronic areas of the Marche region, that represent a privileged research laboratory. Empirical data were collected following a multiple case-study design with replication logic.

As far as the structure of this work is concerned, in the first part a deeper analysis of the international management literature is carried out, in order to place the study within the framework of the main research threads. Some hypotheses for research that we are studying are also formulated. These hypotheses concern the most representative business cases, among those analysed, in the mechanical and electronic sectors that represent a privileged research laboratory. Following this, the results that emerge from the empirical research are highlighted. In essence, they regard as the strategies of internationalization of production and R\&D activities. The complex strategies of multi-positioning in international value chains that MSMs find themselves involved in are particularly focused, another area focused on regards the impact of innovative activities that production plants have on the performance of the subsidiaries. Finally, a particular emphasis is placed on headquarters-subsidiary relationships, the entrepreneurial best practices that have been identified, and the appropriation of research carried out by foreign units.

\section{Theory and Hypothesis}

The objective of this study is to empirically validate the positive effect of collaborative process competence and the level of engagement on the operational and relational success of a collaborative effort. In the end, we will show that collaborative process competence mediates the relationship between new technological processes and collaborative engagement, and positively influences both operational and relational outcomes.

Building from two theoretical foundations, the knowledge-based (KBV) (Kogut \& Zander, 1992) and relational view (RV) of the firms, we view collaboration as a mechanism to combine and deploy external and internal knowledge and skills, and examine how a specific capability-collaboration process competence-positively influences the operational and relational outcomes of such contractual collaborative initiatives.

KBW suggests the role of the firm is to create, acquire, and deploy organizational knowledge (Nonaka, 1994). Other authors note the importance of customers and suppliers as sources of external knowledge that complement an organization's own internal knowledge (Paulraj, Lado, \& Chen, 2008; Schiele, Horn, \& Vos, 2011; Tallman \& Chacar, 2011).

RV theory has historically focused on strategic alliances and long-term relationships. Historically, collaboration research has focused on long-term collaborative relationships (Dyer \& Singh, 1998; Oettl \& Agrawal, 2008). Currently, firms who invest in long-term relationships to combine resources in unique ways have not been able to realize a competitive advantage and there are not any "relational rents". A long-term relationship orientation is an important precursor to building relational competencies that improve collaborating firms' performance. Yet many collaboration efforts are episodic in nature, focused on episodic contractual initiatives, with a defined beginning and end, occurring in a limited timeframe, and taking place between specific organizations (firms, research groups, universities, government authorities, etc.) or teams within firms.

This research makes several empirical contributions to the existing literature. Finally, we offer suggestions for managers to improve the effectiveness of inter-firm collaboration initiatives and discuss future research opportunities. 
To meet the complex challenges presented by globalization and technological change, managers must adopt an entrepreneurial mindset and emphasize both exploration and exploitation type-opportunities (Hitt, Ireland, Camp, \& Sexton, 2001; Gedajlovic, Cao, \& Zhang, 2012; Gupta, Smith, \& Shalley, 2006; Shane \& Venkataraman, 2000).

It is argued that when entrepreneurial firms decide to internationalise their production and $R \& D$ areas through foreign direct investment (FDI) high or full equity they are torn between being different and being the same. Some firms are capable of differentiating competitively by improving the production processes of the foreign plant and connecting forms of technologically-based cooperation, in order to take up new business opportunities in foreign markets that are experiencing strong growth. This improves innovative performance significantly. However, in a few cases one can come across situations in which internationalisation bases itself on the replication of the domestic plant, having the objective of both meeting an expanding demand and exploiting on a wider scale the resources employed in R\&D processes (internationalisation asset exploitation).

Entrepreneurial firms thus face the tension between strategic conformity and differentiation ${ }^{1}$.

In this article we have applied a process view to the internationalisation actions of given activities in internationalisation strategies of medium multinational enterprises (MNEs) and explored management issues and the entrepreneurial role in relation to this process. Drawing on insights from entrepreneurial-oriented literature, the concept of entrepreneurial orientation suggested in this paper focuses on the analysis of corporate entrepreneurship, or widespread entrepreneurship in a form of corporation that allows for the entrepreneurial actions of employees.

Thus, entrepreneurial orientation refers to the positive bias of the company to new business opportunities. Entrepreneurial orientation is essential for the creation and development of initiatives and competences in subsidiaries (Birkinshaw \& Hood, 1998), but it involves more than just the creation of a new business or new production method. It involves credibility and freedom in taking risky decisions and indicates a company's willingness to act proactively in the face of a risky decision-making environment.

Thus, one expects multinationals fostering an entrepreneurial spirit to be concerned with the development of innovations in their subsidiaries because the entrepreneurial stimulus is an important mechanism for the development of novel competitive advantages (McGrath, MacMillan, \& Venkataraman, 1995). The subsidiaries that act more independently are seen as those with the highest degree of entrepreneurship; they thus generate a greater number of initiatives (Verbeke \& Yuan, 2007).

H1: The support and experience of members of the owner-family and of senior management are fundamental in increasing the capabilities focused on the development of innovation activities.

This study aims to understand what factors allow subsidiaries of emerging medium multinationals to develop innovation through an increasing internationalisation of production activities and the consequent increase in the decentralisation of R\&D (Rugman \& Verbeke, 2001; Shotter \& Beamish, 2011; Borini, Oliveira, Silveira, \& Concer, 2012) ${ }^{2}$.

Today, technology transfer occurs in several directions that are contrary to traditional directions: from

\footnotetext{
${ }^{1}$ It is a question concerned with both entrepreneurship research and strategic management literature: whether entrepreneurial firms should conform to prevailing practices or deviate through innovation (Amason, Shrader, \& Tompson, 2006; J. E. Jennings, P. D. Jennings, \& Greenwood, 2009; Tan, Shao, \& Li, 2013). It is argued that firms gain competitive advantages by being different (Barney, 1991; Porter, 1991), whereas they obtain legitimacy by being similar (Pfeffer \& Salancik, 1978; Scott, 1995).

${ }^{2}$ Outsourcing knowledge and innovation activities offer cost savings and superior performance, but can also put a firm's unique resources and capabilities at risk.
} 
developing to developed countries and from subsidiaries to the parent company. Corroborating this idea, the authors argue that the main reason for the existence of medium-sized multinational corporation is its capability to internalize resources and transfer knowledge and technology within its network more effectively than market mechanisms can (Dunning, 1980; Foss \& Pedersen, 2002; Meyer, Mudambi, \& Narula, 2011; Mudambi \& Swift, 2011; Bhupatiraju, Nomaler, Triulzi, \& Verspagen, 2012) ${ }^{3}$.

Whereas the home-country subsidiary is perceived as scoring high on trust and in need of less checks and controls, the headquarters is currently involved in an organizational change process within the foreign subsidiary where trust and control are explicit issues. A recent development in this debate is the duality perspective proposed by Möllering (2005). Others stress that relational governance functions, but formal contracts, are complementary to trust, coexisting, and jointly contributing to the development of a relationship (Poppo \& Zenger, 2002; Håkansson \& Ford, 2002; Ness \& Haugland, 2005).

H2a: The reverse transfer of innovation relies on a strong integration (communication) between the parent company and its subsidiaries.

H2b: The relationship between management support and innovation performance is more positive under low rather than high levels of risk control.

In acquisition-focused literature, some authors distinguishes strategic from organizational fit, arguing that strategic fit, which refers to similarities in technology, products, and markets, is distinct from organizational fit, or similarities in terms of organizational processes, such as culture and human resource policies (Jemison \& Sitkin, 1986; Nielsen \& Gudergan, 2012) ${ }^{4}$. Existing fit constructs in alliance literature tend to focus on either resource-based matching of capabilities or strategic congruence (inter-partner compatibility or complementarity, inter-firm diversity, etc.). In the case of the former profile, consistent with the resource-based view (RBV), alliances allow firms to trade strategic resources across their boundaries. When these resources are complementary, desirable performance arises due to synergistic effects.

Smaller firms can leverage corresponding advantages in alliances. Among these, a smaller firm's flexibility and ability to recognize and act on business opportunities quickly have been acknowledged as important in the innovation process (Maskell \& Malmberg, 1999; Thorgren, Wincent, \& Håkan, 2012).

Developed hypotheses are built on the argument that smaller firms are more inclined to adjust to their partners and conform to the cooperative informal norms. This behavior subsequently becomes a useful way for small firms to be innovative in terms of the number of new design-engineering-production processes they develop in many international business markets.

H3: The technical capacities of the partners act as a positive and significant influence on the flexible governance of the alliance.

Recent literature on the multinational corporation (MNC) has emphasized the role of knowledge in creating a competitive advantage (Bartlett \& Ghoshal, 1989; Grant, 1996; T. Ambos \& B. Ambos, 2009). Knowledge flows between the headquarters and subsidiaries provide opportunities to distribute best practices (Kogut \& Zander, 1992), to learn from offshore affiliates or to create completely new sources of competitive

\footnotetext{
${ }^{3}$ Reverse innovation has been proposed by Hakanson and Nobel (2001) who show the importance of reverse technology transfer associated with the characteristics of technology, innovativeness, integration and external network embeddedness. Reverse innovation enables access to a variety of local knowledge and facilitates the coordination of a global strategy, the creation of new products, the improvements of production processes, and the increase of international business markets opportunities.

${ }^{4}$ Regarding contingency theory (Lawrence \& Lorsh, 1967; Miles \& Snow, 1978).
} 
advantage (Doz, Santos, \& Williamson, 2001; Ambos \& Schlegelmilch, 2007).

Internal knowledge transfer is defined as specific, purposeful, directed projects between two or more corporate units, delimited in time and effort, with the explicit aim that the recipient subsidiary will use the transferred knowledge (Szulanski, Cappetta, \& Jensen, 2004). This definition implies that transfer performance relate to both efficiency and effectiveness.

The foreign subsidiary is more likely to depend on its local suppliers to gain access to needed information and resources in that it is unfamiliar with the local environment. Based on transaction cost theory, the pure market contract incurs higher mal-adaptation cost when the dependence of both parties increases. In this regard, closer relationships rather than pure market contracts will be preferred. Thus, both parties invest efforts in maintaining the relationship and attain to higher adaptation.

H4: For a medium multinational subsidiary acting as a buyer, a higher degree of adaptation will lead to higher performance.

Two characteristics of firm-level capability are relevant to the cost of integrating the knowledge process: the tacitness of the technology involved in the process, and the human asset specificity of the process.

H5a: The more a knowledge process requires task integration (partner-specific resource adaptation), the more likely it is that it will be organized as an institutional alliance.

H5b: In addition, the more tacit are knowledge processes, due to their customized or specialized nature, the more investments in inter-firm relationship are required to make partnership effective.

The medium-sized firm's internationalization has been a prominent phenomenon for a long time now, and this situation has increasingly attracted attention from the academic community. See Figure 1, which highlights a structural model of the research.

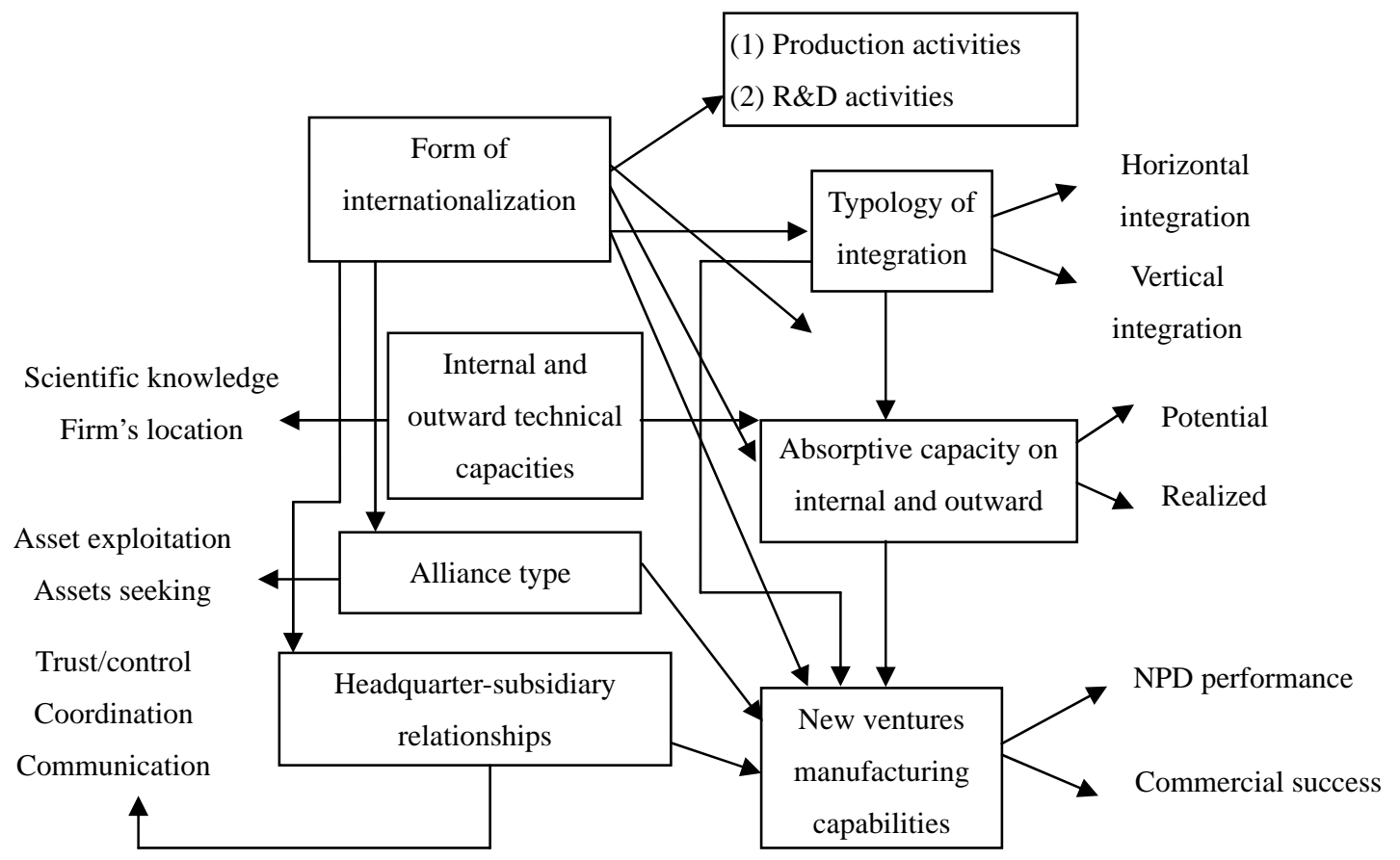

Figure 1. Structural research’s model. Source: Our elaboration. 


\section{Research Method}

An interpretative, qualitative approach—utilizing selected multi-case study interviews (Yin, 2003; Eisenhardt \& Graebner, 2007) such as the primary data collection method-is chosen because it helps to navigate and understand the complex issues that are associated with the data quality concept, and its relation to the factors involving managerial practices to implement facilities in design and marketing activities. Case studies investigate the issue within a real-life context, drawing on the reviews of a number of sources and provide the means to review the theory and practice iteratively. Multiple cases ensure that common patterns are identified rather than generalized from what might be change occurrences (Eisenhardt, 1989; Janesick, 2000).

The qualitative case study has been defined as an empirical research that primarily uses contextually rich data from bounded real-world settings to investigate a focused phenomenon (Meredith, 1998; Stuart, McCutcheon, Handfield, McLachlin, \& Samson, 2002; Eisenhardt \& Graebner, 2007).

To reduce any potential sources of bias, multiple data sources were used (multiple interviews, review of internal documents, and e-mails, etc.) to minimize interpretative problems. In-depth interviews and data collection were performed over a 10-year period (from 2000 to 2009).

We have adopted several data sources: semi-structured interviews (the interview tool is updated based on emerging data), observations (plant tours, attendance at meetings), and archival sources (documents, production, and marketing statistics, etc.).

This study surrounding the relationship-building approach and the international marketing strategies adopts a multi-phase methodology. It is divided into research stages of pilot investigation and empirical model validation, conducted in sequential order during a multiyear period. Such an arrangement helps to integrate and reconfigure a variant view in relevant studies, proposing a framework to be verified in the samples representing different fields of the firm. The pilot investigation phase, comprising an initial exploration and small-scale survey, entails the conceptual framework of relationship-building in international knitwear supply chains. The empirical model validation phase, using data obtained from wider surveys, completes the empirical verification of new cycles of international business for the management of international strategies.

\section{Multi-plant Production System and Knowledge Process Decentralization}

In a globally competitive environment, the generation and transfer of knowledge are keys to sustainable competitive advantage, and knowledge management is fundamental to firm survival and growth (Foss \& Pedersen, 2002; Grant, 1996; Mudambi \& Tallman, 2010).

This study examines whether and to what extent medium multinational enterprises use outward foreign investment both in emerging-markets and in developed markets, to capture knowledge spillovers so as to improve their technological capabilities at home ${ }^{5}$.

In the next section we consider specific theoretical perspectives (resource-based theory (RBT), TCE, and transactional value) that have been applied to both production internationalization and to foreign alliance

\footnotetext{
5 The knowledge seeking motivation for outward foreign direct investment (OFDI) is particularly emphasized by the literature on the internationalization of firms from emerging and developing markets (Chen, Li, \& Shapiro, 2012).
} 
structures in order to better understand the use of different governance forms in knowledge process growth.

RBT (Barney, 1991; Peteraf, 1993) emphasized the value of leveraging scarce firm-specific resources through business relationships. Complex, tacit, embedded, and diffuse firm-specific knowledge is generally the key to sustainable competitive advantage in RBT.

RBT as applied to the use of alliances offers an internally consistent, comprehensive theoretical explanation for this decision. As such, RBT can also be used to explain the decision to move from in-house knowledge sourcing to a knowledge process outsourcing alliance.

Alliance theory suggests that alliances can be structured to reduce transactional uncertainty and therefore encourage transaction-specific investment by both vendor and industrial clients in the customization of their processes to each other's needs (Hennart, 1988; Williamson, 1991; Parkhe, 1993; Grimpe \& Kaiser, 2010).

It has been affirmed that different actors, especially headquarters and new venture (subsidiary) managers, will have divergent ideas as to how attention should be optimally allocated, creating a non-trivial matching problem of attention seekers and providers in the organization. The headquarters, for their part may want to support subsidiaries' operations, transfer knowledge, ensure coordination or strengthen their control and limit disruptive behavior. Subsidiaries, on the other hand, are competing for headquarters' attention to acquire resources, to augment their market mandate, to increase their bargaining power, or try to avoid intervention (Ambos \& Birkinshaw, 2010). In the cases that have been studied we have observed that this dichotomy of objectives emerges from the very outset, in spite of the substantial absence of a foreign management that is well-structured and autonomous.

Our definition of knowledge processes does not include highly standardized or codified processes that simply can be purchased in an arm's length transaction.

International knowledge processes have a number of distinctive characteristics, including: high levels of risk and uncertainty regarding outcome; information asymmetry in relation to judgments of information quality; co-production of knowledge by the client firm and the supplier; potential impact in medium-sized multinational's core competencies and capabilities; difficulty of reversing the sourcing decision due to technical capacity; relative uniqueness of each information exchange; and the tacit nature of the information exchange.

In this study we investigate the influence of subcontracting in production-related jobs, outsourcing and collaborations with non-supply chain partners on small subsidiaries’ operational innovation.

The internationalization of $R \& D$ is increasingly recognized as an important strategy for firms to foster their technological capabilities and result in better competitive advantages. The actions of $R \& D$ internationalization by firms may focus on creating knowledge across national boundaries. Today, firms dispersing their knowledge of R\&D activities but also build up a learning network which can explore and exploit knowledge on a global scale.

Absorptive capacity is composed of three elements (Cohen \& Levinthal, 1990): the recognition of the value of new information, accumulation (internalisation, acquisition) of information, application, and employment of information for commercial purposes. This vision emphasizes the importance of external knowledge, rather than that of internally created knowledge. Lane, Koka, and Pathak (2006) defined absorptive capacities as being the ability of a firm to utilize knowledge that is present externally through four sequential 
processes:

- Recognition and comprehension of new knowledge, that is potentially marketable, that is external to the firms, through processes of explorative learning;

- Assimilation of new knowledge (of the type that is positively valued) through learning processes that in some cases, if required prove to be efficacious if they are modified appropriately;

- Employment of externally assimilated knowledge in internal innovative processes, with the aim of creating and exploiting new knowledge;

- Constitution of organizational learning process that is efficient and capable of prolonging the long-term commercial performance of output (firm products) (exploitative learning) ${ }^{6}$.

Lane et al. (2006) introduced some factors firm-based (or internal drivers) that significantly influence the ACAP (absorptive capacities) of an organisation. These internal drivers are characteristics that are pertinent at the components and structure of an organization (the mental model of the members, characteristics of the structure and of the processes of the firm, and strategic direction of the firm) ${ }^{7}$.

The governance of decentralized high-value knowledge processes is typically managed through extended internal-contacts (among managers, members of the entrepreneurial nucleus, and heads of department) requiring mutual commitment and resource specialization. Moreover, alliances constituted by plants of foreign subsidiaries with foreign partners (competitors, buyers, suppliers of technologies, research institutions, etc.) bring specific benefits and limitations to transacting partners.

Tallman and Shenkar (1994) suggested that alliances can supplant failed markets when there is a need for transaction-specific investment in order to protect shared tacit resources, and alliances can replace failed internal expansion for non-core activities involving complementary assets that the firm does not own or control.

\section{Multi-plant research Activities: Opportunity for Growth}

The ultimate objective for medium-sized multinationals as regards knowledge-seeking investments in emerging business markets is to improve their technological capabilities. The literature provides some explanations as to why this is the case. In this study at least two of these explanations are verified. Firstly, medium-sized multinationals often wish to reduce their reliance on foreign technologies, and to develop "indigenous knowledge" and "indigenous innovation”. Secondly, most medium-sized multinationals still lack the capability to coordinate global R\&D activities, and they renounce the option of concentrating technological development processes at home (Luo \& Tung, 2007; Marcone, 2012).

In the following matrix (see Figure 2), two forms of internationalisation are identified, that have been in the main adopted by the firms investigated. Such forms have been identified on the basis of variables, such as the knowledge of foreign business markets and the necessity/will put into practice specific research activities to check them.

\footnotetext{
${ }^{6}$ For organizational barriers to learning (Schilling \& Kluge, 2009).

7 In a recent contribution, the following have been identified: indicators to measure the quality of learning processes, that are geared towards exploration, transformation, and exploitation of technological and market knowledge, and towards evaluating the effects produced on the technological assets of the firm, as well as market performance.
} 


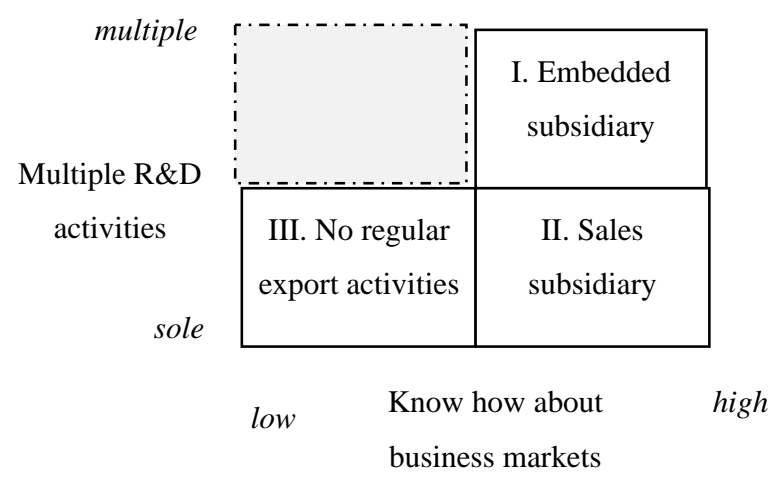

Figure 2. Multiple R\&D activities in foreign business markets. Source: Our elaboration based on empirical research.

In the top right quadrant the foreign subsidiaries are highlighted, the consequence of FDI high equity that adds to a firm's product diversification and that has a great chance to survive. Regarding parent firm characteristics, empirical studies observe lower rates for firms that possess host country experience and technological advantage (Delios \& Beamish, 2001). The presence in this group of many of the subsidiaries that have been analysed, strengthens the theoretical construct regarding the operational flexibility of medium-sized multinationals (Fisch \& Zschoche, 2012). The concept of operational flexibility states that a primary advantage of multinational corporations is the flexibility to transfer resources, e.g., production capacity, between locations in different countries as a reaction to environmental changes.

In the second quadrant one can insert forms of internationalization that are exclusively commercial, taken up by those medium-sized multi-nationals that decide to utilize domestic know-how (asset seeking internationalization), with the aim of increasing the commercial presence in the business markets of emerging nations (with a strong growth in demand), and in which significant experiences of marketing have been developed.

Many of the medium-sized multinationals investigated have set up forms of internationalisation, of both a production-based and commercial nature, and therefore are present in the two quadrants on the right (in the first and second quadrant). A differentiation between subsidiaries which are the sole investment and subsidiaries which are not the sole investment in a country clarifies that, according to the logic of operational flexibility, location characteristics of the production network are only relevant to the decision of investment.

Our empirical study demonstrates that international exploration studies with "embedded subsidiaries” and international exploitation strategies with "sales subsidiaries" are separate (though not necessarily antithetical) strategies with different antecedents and performance consequences. Even if both are necessary for long-term competition, they remain fundamentally different because they require substantially different structures, processes, strategies, capabilities, and cultures and effect firm adaptation and performance differently (O’Reilly \& Tushman, 2008; Nielsen \& Gudergan, 2012).

Only in some sporadic cases have the MSMs analysed exported in new and unknown markets, carrying out production and research activities, in other words, the entire process of design-engineering-production internally (quadrant III).

Regarding heterogeneity, few studies so far (Salomon \& Jin, 2010) had addressed firm heterogeneity in learning from exporting. 
As is well known, the risks of innovative activities are determined in mainly by the two following aspects: firstly by the uncertainty that regards both the future development of technology and its potential application in intermediate (business) and final (consumer) markets; secondly, by the effect of cannibalization that innovative investments almost always exert on prior investments. Moreover, some of the firms investigated tend to enhance their dependence on other firms to acquire needed resources, and thus to develop a close relationship (Skarmeas \& Robson, 2008). However, this type of relationship is preferable to market contracts because it favours reciprocal adaptation without opportunistic practices.

We can further distinguish what has been described as the co-specialized knowledge process (Doz et al., 2001; Mudambi \& Tallman, 2010). In this case, in order to maximize joint production of a knowledge process, the partner firms share the risk by specializing and adapting its processes to the needs of the other ${ }^{8}$.

Many studies assume that the productivity of researchers depends positively on domestic and foreign inter-temporal knowledge spillovers and negatively on market size measured by the number of consumers buying each product (Rivera-Batiz \& Romer, 1991; Dinopoulos \& Unel, 2011).

They find that intensity (strength) of international knowledge spillovers increases the productivity of researchers engaged in the discovery of new varieties and accelerates long-term growth. They also affirm that quality uncertainty implies that firms engaged in $R \& D$ activities to discover new products are not aware of their exporting status in advance, which depends on the quality of their products. This is because trade liberalization, measured by a reduction in trade costs or a decline in foreign market entry costs, generates a reallocation of resources from low-quality in high-quality products and leads to the exit of inefficient firms.

Thus the entry into the innovation process depends inversely on the level of expected instantaneous costs required to enter the domestic and foreign markets. Many medium-sized enterprises must invest resources in new, complex, and co-managed $R \& D$ activities, while a great number of markets are liberalized (one can think of China): Only in this way can they increase the quantity of products and the qualitative level of new products offered in international business markets.

\section{Multi-positioning in International Value Chain}

Following a knowledge spillover literature, we suggest that by locating in foreign business markets, subsidiaries of MSMs can benefit from knowledge spillovers (e.g., technology and know-how spillovers) from local companies in the host markets (Atkinson \& Stiglitz, 1969; Mansfield \& Romeo, 1980). Knowledge can be spilled over to subsidiaries of MSMs through several channels.

First, the subsidiaries can acquire knowledge by participating in the local supply chain. Studies have shown that knowledge spillovers are associated with purchases and usage of high-technology intermediate products made by local suppliers.

In this study we have investigated the influence of subcontracting in production related outsourcing and collaborative partnerships of small subsidiaries with firms outside the local firms' supply chain (Frohlich \& Westbrook, 2001; Oke \& Kach, 2012). In this sense, small subsidiaries take up forms of collaboration with new supply chain partners. They position themselves within multiple international supply chains. The problems and

\footnotetext{
8 That is, value maximization comes not just from the joint application of superior processes to the needs of the others in the process of task integration, creating what Madhok and Tallman (1998) called collaboration-specific quasi-rents based on partner-specific investments in the transaction.

${ }^{9}$ However, there is evidence that exporters are more productive than non-exporters (García, Avella, \& Fernández, 2012).
} 
the opportunities that collaboration with non-supply chain partners has on the operational innovation of non-supply chain partners seem evident.

Secondly, the subsidiaries can access and assimilate advanced technologies and know-how by interacting with local technological and innovative leaders such as workers in local companies which engineer like capabilities, research labs, and universities. The know-how and the assimilation of new technologies enable the small subsidiary to focus better on its core competencies. Furthermore, they provide the subsidiary with an opportunity to be exposed to new and different learning experiences ${ }^{10}$. Undoubtedly, the subsidiaries that act more independently are seen as those with the highest degree of entrepreneurship. They therefore generate a greater number of initiatives.

\section{The Impact of a Subsidiary's Operational Innovation on Its Performance}

Operational innovation is a result of how well a firm can combine internal and external knowledge to develop innovative processes and methods (Oke \& Kach, 2012). Such abilities to sense, respond, and leverage the environment should enhance financial performance. Indeed, the pursuit of an innovation in smaller organizations is typically justified by its perceived impact on financial performance (Freel, 2000; Wolff \& Pett, 2006). More specifically, operational innovation can enhance a firm's financial performance directly through increased revenues. Furthermore, improvements in manufacturing capabilities allow for reduced costs, improved quality, and a reduced cycle time. For instance, operational innovation leads to improvements in manufacturing capabilities, which may lead to superior market performance.

Although foreign direct investment enables small subsidiaries to access external knowledge, as posited by the KBW, the subsidiary's operational innovation can act as a conduit for this external knowledge to be better leveraged.

This research however, highlights how, in the case of small subsidiaries, there is a very strong connection between the capacity to acquire know-how externally and the improvement of financial performance. The bond between the value of acquired know-how and the entity of resources (material and immaterial resources) actually invested in internal operational innovations seems to be less significant.

\section{Headquarter-Subsidiary Entrepreneurial Relationships}

Product market and technological innovation have long been known to contribute to firm success. Correspondingly, top-level managers are increasingly recognizing the need to respond to the entrepreneurial imperatives created by their competitive landscapes. However, managers at all levels of the organization can be instrumental in fostering entrepreneurial activity leading to productive innovation results (Kuratko, Ireland, \& Hornsby, 2005; Hornsby, Kuratko, Shepherd, \& Bott, 2009; Ireland, Covin, \& Kuratko, 2009; Goodale, Kuratko, Hornsby, \& Covin, 2011). Recognizing the role of an organization's broad membership in the perpetuation of innovation, the concept of corporate entrepreneurship-as-strategy represents a really entrepreneurial orientation and an entrepreneurial opportunity.

The support and the experience of "expatriate entrepreneur" (a member or owner family nucleus) senior management in entrepreneurial activities in subsidiary are more and more important in creating and stimulating the organizational environment for new business ideas and practices. Naturally, the relationship between

\footnotetext{
10 This is particularly true for small firms because such firms may lack the capabilities and resources to pursue broad strategies.
} 
entrepreneurial orientation and the development of capabilities requires the constant rebuilding of businesses and processes in a continuous and emerging manner.

It has recently been suggested that control can produce trust when not denying or eliminating the other agents. However many studies highlight how controls which restrain the freedom of others may be compatible with trust. Control activities explained by environmental risks rather than relational risks can seemingly restrain the other's freedom of action without a negative impact on trust (Hagedoorn \& Duysters, 2002; Huemer, Boström, \& Felzenstein, 2009). In particular, both formal forms of behaviour control, output control, or socialization processes can be regarded as sources of information used to support the initiatives taken, with the aim of taking advantage of business opportunities, even with partner auxiliaries, rather than being used to contrast strategic initiatives abroad (it is even considered to represent an attack/as being offensive). Trust can be viewed as an appropriate mechanism to facilitate the adaptation process ${ }^{11}$.

\section{Conclusions}

In today’s dynamic environment, firms embedded in more and more diversified international supply chains must collaborate with other firms to pursue episodic initiatives, whether or not a formal alliance or long-term relationship exists. The resolution of a significant quality problem, a supply chain collaboration redesign, contingency planning, or a new product launch is examples.

This research, based on two theoretical foundations, the KBV, and RV of the firm, design and builds a framework of management practices in order to facilitate the collaborative relationships among medium-sized Italian firms that operate in international business markets and frequently vary their positioning in international supply chains.

This study also based on embeddedness theory and transaction cost theory, explores the influence of innovation and adaptation, which benefit from a quality relationship between subsidiaries of foreign medium multinationals and local partners (suppliers, innovative industrial clients, other institutions, etc.) and on the corporate performance of foreign subsidiaries.

This study highlights how smaller firms gain advantages through exchange strategies in alliances. A specific type of alliance, namely, multi-partner alliances engages small subsidiaries in multiple and diversified value-chain activities, such as collaborative research, development, or sourcing of technologies. The most significant result that would merit being followed up in future research is the progressive presence of medium-sized Italian firms within a plurality of demand chains, in the international business market, headquarters of FDI high or full equity.

Therefore, the results demonstrate that a careful management of diffusing knowledge, related to intra- and inter-firm relationships is a relevant task when firms internationalise product activities.

The paper provides many implications for management practice and avenues for future academic research.

It would be worthwhile at this point to focus on some of the most poignant conclusions that have emerged from the research.

(1) Based on knowledge transfer literature, it is possible to observe that medium Italian multinationals tend to increase their R\&D spending level, increasing the number of productive plant in foreign business markets. At the early stage of R\&D internationalization, firms act to decentralize and implement diverse search and option

11 Transaction cost theory's notion of asset specificity, which refers to investments that are idiosyncratic to a focal relationship, is related closely to the concept of adaptations. 
seeking activities. However, the absorption knowledge transferred from subsidiaries, as well as to combine it with their existing knowledge to innovate, they are marginal processes, or even absent: The increased R\&D spending for these two purposes enhances parent firms' technological capabilities only minimally.

Our new conceptualization provides an integrated perspective on resource integration and transaction specificity in the knowledge governance decision. The paper illustrates the dynamics and learning involved in knowledge outsourcing by identifying distinct paths to international research-based alliances.

(2) Knowledge process projects, through direct internationalization of productive activities can be considered as the outsourcing of firm activities that directly involve the production of knowledge and innovation, and that involve some degree of firm-specific capabilities.

The resulting conceptual model and propositions raise important issues regarding organizational competence and organizational design for monitoring and coordinating knowledge transfer.

(3) Knowledge spillovers are necessary for medium-sized parents to benefit from "foreign knowledge", but they are not sufficient. For the parent to benefit, knowledge spillovers in the host markets must be accompanied by internal transfer mechanisms in order for there to be a positive reverse spillover effect.

The foreign subsidiary's relationship with the local supplier could serve as a navigator to adapt better to the local market. This has been proved by this study.

(4) This research highlights how important it is for small subsidiaries to acquire knowledge continually through innovating operations, and how this link has had a positive impact on financial performance. In effect, the success of industrial marketing strategies is based on the strategic competitiveness of operations. It is precisely the importance of innovation in operations, both for the parent firm and for the foreign subsidiary that explains the competitiveness of medium-sized Italian multinationals that are notoriously unprotected by patents (regarding both products and processes).

The ulterior contribution is in highlighting the importance of the presence of a growing number of small innovative subsidiaries in international supply chains. The importance of de-specialization in the supply chain management and with collaboration strategies suggest focusing on a multiplicity of activities that may be related to the organization's goals that are in a state of continual change.

(5) This study shows that a new international firm which has a high level of strategic choice and receives attention from the headquarters, in the sense that the summit powers (both entrepreneurial and managerial) is the same, perform better than other equity international cooperative forms. More specifically, it has been found that the interactions of subsidiaries' autonomy, inter-unit power, and initiatives with attention increase subsidiary performance.

Corporate entrepreneurship refers to the pursuit of entrepreneurial actions and initiatives that transform the established organization through strategic renewal processes and extend the firm's scope of operations into domains, that is, new product-market business segments or technological arenas.

\section{References}

Almeida, P., \& Kogut, B. (1997). The exploration of technological diversity and the geographic localization of innovation. Small Business Economics, 9(1), 21-31.

Amason, A. C., Shrader, R. C., \& Tompson, G. H. (2006). Newness and novelty: Relating top management team composition to new venture performance. Journal of Business Venturing, 21(1), 125-148.

Ambos, B., \& Birkinshaw, J. (2010). Headquarters' attention and its effect on subsidiary performance. Management International Review, 50(4), 449-469. 
Ambos, T., \& Ambos, B. (2009). The impact of distance on knowledge transfer effectiveness in multinational corporations. Journal of International Management, 15(1), 1-14.

Ambos, T., \& Schlegelmilch, B. B. (2007). Innovation and control in the multinational firm: A comparison of political and contingency approaches. Strategic Management Journal, 28(5), 473-486.

Atkinson, A. B., \& Stiglitz, J. E. (1969). A new view of technological change. The Economic Journal, 79(315), 573-578.

Barney, J. (1991). Firm resources and sustained competitive advantage. Journal of Management, 17(1), 99-120.

Bartlett, C. A., \& Ghoshal, S. (1989). Managing across borders: The transnational solution. Boston: Harvard Business School Press.

Bhupatiraju, S., Nomaler, Ö., Triulzi, G., \& Verspagen, B. (2012). Knowledge flows-Analyzing the core literature of innovation, entrepreneurship and science and technology studies. Research Policy, 41(7), 1205-1218.

Birkinshaw, J., \& Hood, N. (1998). Multinational subsidiary development: Capability evolution and charter change in foreign-owned subsidiary companies. Academy of Management Review, 23(4), 773-795.

Borini, F. M., Oliveira, M. M., Silveira, F. F., \& Concer, R. O. (2012). The reverse transfer of innovation of foreign subsidiaries of Brazilian multinationals. European Management Journal, 20(3), 219-231.

Chen, V. Z., Li, J., \& Shapiro, D. M. (2012). International reverse spillover effects on parent firms: Evidences from emerging-market MNEs in developed markets. European Management Journal, 30(3), 204-218.

Cohen, W. M., \& Levinthal, D. A. (1990). Absorptive capacity: A new perspective on learning and innovation. Administrative Science Quarterly, 35(1), 128-152.

Conner, K. R., \& Prahalad, C. K. (1996). A resource-based theory of the firm: Knowledge versus opportunism. Organization Science, 7(5), 477-501.

Delios, A., \& Beamish, P. W. (2001). Survival and profitability: The roles of experience and intangible assets in foreign subsidiary performance. Academy of Management Journal, 44(5), 1028-1038.

Dinopoulos, E., \& Unel, B. (2011). Quality heterogeneity and global growth. European Economic Review, 55(5), 595-612.

Doz, Y., \& Hamel, G. (1998). Alliance advantage: The art of creating value through partnering. Boston, M.A.: Harvard Business School Press.

Doz, Y. L., Santos, K., \& Williamson, P. (2001). From global to metanational: How companies win in the knowledge economy. Boston, M.A.: Harvard Business School Press.

Dunning, J. H. (1980). Toward an eclectic theory of international production: Some empirical tests. Journal of International Business Studies, 11(1), 9-31.

Dyer, J. H., \& Singh, H. (1998). The relational view: Cooperative strategy and sources of interorganizational competitive advantage. Academy of Management Review, 23(4), 660-679.

Easterby-Smith, M., Lyles, M. A., \& Tsang, E. W. K. (2008). Inter-organizational knowledge transfer: Current themes and future prospects. Journal of Management Studies, 45(4), 677-690.

Eisenhardt, K. M. (1989). Building theories from case study research. Academy of Management Review, 14(4), 532-550.

Eisenhardt, K. M., \& Graebner, M. E. (2007). Theory building from cases. Academy of Management Journal, 50(1), 25-32.

Fisch, J. H., \& Zschoche, M. (2012). The effect of operational flexibility on decisions to withdraw from foreign production locations. International Business Review, 21(5), 806-816.

Foss, N., \& Pedersen, T. (2002). Transferring knowledge in MNCs: The role of sources of subsidiary knowledge and organizational context. Journal of International Management, 8(1), 49-67.

Freel, M. S. (2000). Do small innovating firms outperform non-innovators? Small Business Economics, 14(3), 195-210.

Frohlich, T. M., \& Westbrook, R. (2001). Arcs of integration: An international study of supply chain strategies. Journal of Operations Management, 19(2), 185-200.

García, F., Avella, L., \& Fernández, E. (2012). Learning from exporting: The moderating effect of technological capabilities. International Business Review, 21(6), 1099-1111.

Gedajlovic, E., Cao, Q., \& Zhang, H. (2012). Corporate shareholdings and organizational ambidexterity in high-tech SMEs: Evidence from a transitional economy. Journal of Business Venturing, 27(6), 652-665.

Goodale, J. C., Kuratko, D. F., Hornsby, J. S., \& Covin, J. G. (2011). Operations management and corporate entrepreneurship: The moderating effect of operations control on the antecedents of corporate entrepreneurial activity in relation to innovation performance. Journal of Operations Management, 29(1), 116-127.

Grant, R. M. (1996). Prospering in dynamically-competitive environments: Organizational capabilities as knowledge integration. Organization Science, 7(4), 375-387. 
Grimpe, C., \& Kaiser, U. (2010). Balancing internal and external knowledge acquisition: The gains and pains from R\&D outsourcing. Journal of Management Studies, 47(8), 1483-1509.

Gupta, A. K., Smith, K. G., \& Shalley, C. E. (2006). The interplay between exploration and exploitation. Academy of Management Journal, 49(4), 693-706.

Hagedoorn, J., \& Duysters, G. (2002). Learning in dynamic inter-firm networks: The efficacy of multiple contacts. Organization Studies, 23(4), 525-548.

Hakanson, L., \& Nobel, R. (2001). Organization characteristics and reverse technology transfer. Management International Review, 41(4), 392-420.

Håkansson, H., \& Ford, D. (2002). How should companies interact in business networks? Journal of Business Research, 55(2), 133-139.

Hennart, J. F. (1988). The transaction cost theory of equity joint ventures. Strategic Management Journal, 9(4), 361-374.

Hitt, M. A., Ireland, R. D., Camp, S. M., \& Sexton, D. L. (2001). Strategic entrepreneurship: Entrepreneurial strategies for wealth creation. Strategic Management Journal, 22(6-7), 479-491.

Hornsby, J. S., Kuratko, D. F., Shepherd, D. A., \& Bott, J. P. (2009). Manager's corporate entrepreneurial actions: Examining perception and position. Journal of Business Venturing, 24(3), 236-247.

Huemer, L., Boström, G. O., \& Felzenstein, C. (2009). Control-trust interplays and the influence paradox: A comparative study of MNC-subsidiary relationships. Industrial Marketing Management, 38(5), 520-528.

Ireland, R. D., Covin, J. G., \& Kuratko, D. F. (2009). Conceptualizing corporate entrepreneurship strategy. Entrepreneurship Theory and Practice, 33(1), 19-46.

Janesick, V. (2000). The choreography of qualitative research design. In Y. S. Lincoln (Ed.), Handbook of qualitative research (pp. 379-399). California: Sage Publications.

Jemison, D. B., \& Sitkin, S. B. (1986). Corporate acquisitions: A process perspective. Academy of Management Review, 11(1), $145-163$.

Jennings, J. E., Jennings, P. D., \& Greenwood, R. (2009). Novelty and new firm performance: The case of employment systems in knowledge-intensive service organizations. Journal of Business Venturing, 24(4), 338-359.

Johanson, J., \& Vahlne, J. E. (1990). The mechanism of internationalisation. International Marketing Review, 7(4), 11-24.

Johanson, M., \& Lundberg, H. (2007). The impact of geographical proximity and technology on firms' R\&D operations. Finanza, Marketing e Produzione, 1, 123-138.

Kelly, M. (2009). Technological progress under learning by imitation. International Economic Review, 50(2), 397-414.

Keupp, M. M., \& Gassmann, O. (2009). The past and the future of international entrepreneurship: A review and suggestions for developing the field. Journal of Management, 35(3), 600-633.

Knight, G. (2000). Entrepreneurship and marketing strategy: The SME under globalization. Journal of International Marketing, $8(2), 12-32$.

Kogut, B., \& Zander, U. (1992). Knowledge of the firms, combinative capabilities, and the replication of technology. Organization Science, 3(3), 383-397.

Kuratko, D. F., Ireland, R. D., \& Hornsby, J. S. (2005). An examination of manager's entrepreneurial actions and job satisfaction. International Entrepreneurship and Management Journal, 1(3), 28-33.

Lane, P. J., Koka, B. R., \& Pathak, S. (2006). The reification of absorptive capacity: A critical review and rejuvenation of the construct. Academy of Management Review, 31(4), 833-863.

Lavie, D., \& Miller, S. R. (2008). Alliance portfolio internationalization and firm performance. Organization Science, 19(4), 623-646.

Lawrence, P. R., \& Lorsch, J. W. (1967). Organization and environment. Cambridge, M.A.: Harvard University Press.

Lippman, S. A., \& Rumelt, R. P. (1982). Uncertain imitability: An analysis of interfirm differences in efficiency under competition. Bell Journal of Economics, 13(2), 418-438.

Luo, Y., \& Tung, R. L. (2007). International expansion of emerging market enterprises: A springboard perspective. Journal of International Business Studies, 38(4), 481-498.

Madhok, A., \& Tallman, S. (1998). Resources, transactions and rents: Managing value through interfirm collaborative relationships. Organization Science, 9(3), 326-38.

Mansfield, E., \& Romeo, A. (1980). Technology transfer to overseas subsidiaries by U.S.-based firms. Quarterly Journal of Economics, 95(4), 737-750.

March, J. G. (1991). Exploration and exploitation in organizational learning. Organization Science, 2(1), 71-87. 
Marcone, M. R. (2012). Multilocated research strategies of SMEs: Choices of governance. International Journal of Business Competition and Growth, 2(3), 237-255.

Maskell, P., \& Malmberg, A. (1999). Localised learning and industrial competitiveness. Cambridge Journal of Economics, 23(2), 167-185.

McGrath, R. G., MacMillan, I. C., \& Venkataraman, S. (1995). Defining and developing competence: A strategic process paradigm. Strategic Management Journal, 16(2), 251-275.

Meredith, J. R. (1998). Building operations management theory through case and field research. Journal of Operations Management, 16(4), 439-452.

Meyer, K. E., Mudambi, R., \& Narula, R. (2011). Multinational enterprises and local contexts: The opportunities and challenges of multiple embeddedness. Journal of Management Studies, 48(2), 235-252.

Miles, R. E., \& Snow, C. C. (1978). Organizational strategy, structure, and process. New York: McGraw-Hill.

Möllering, G. (2005). The trust/control duality: An integrative perspective on positive expectations of others. International Sociology, 20(3), 283-305.

Mudambi, R., \& Swift, T. (2011). Leveraging knowledge and competencies across space: The next frontier in international business. Journal of International Management, 17(3), 186-189.

Mudambi, S. M., \& Tallman, S. (2010). Make, buy or ally? Theoretical perspectives on knowledge process outsourcing through alliances. Journal of Management Studies, 47(8), 1434-1456.

Ness, H., \& Haugland, S. A. (2005). The evolution of governance mechanisms and negotiation strategies in fixed-duration interfirm relationships. Journal of Business Research, 58(9), 1226-1232.

Nickerson, J. A., \& Zenger, T. (2004). A knowledge-based theory of governance choice: The problem-solving approach. Organization Science, 15(6), 617-632.

Nielsen, B. B., \& Gudergan, S. (2012). Exploration and exploitation fit and performance in international strategic alliances. International Business Review, 21(4), 558-574.

Nonaka, I. (1994). A dynamic theory of organizational knowledge creation. Organization Science, 5(1), 14-33.

O’Reilly, C. A., \& Thusman, M. L. (2008). Ambidexterity as a dynamic capability: Resolving the innovator's dilemma. Research in Organization Behavior, 28, 185-206.

Oettl, A., \& Agrawal, A. (2008). International labour mobility and knowledge flow externalities. Journal of International Business Studies, 39(8), 1242-1260.

Oke, A., \& Kach, A. (2012). Linking sourcing and collaborative strategies to financial performance: The role of operational innovation. Journal of Purchasing and Supply Management, 18(1), 46-59.

Oviatt, B. M., \& McDougall, P. P. (2005). Defining international entrepreneurship and modeling the speed of internationalization. Entrepreneurship Theory and Practice, 29(5), 537-554.

Parkhe, A. (1993). Strategic alliance structuring: A game theoretic and transaction cost examination of interfirm cooperation. The Academy of Management Journal, 36(4), 794-829.

Paulraj, A., Lado, A. A., \& Chen, I. J. (2008). Interorganizational communication as a relational competency: Antecedents and performance outcomes in collaborative buyer-supplier relationships. Journal of Operations Management, 26(1), 45-64.

Penrose, E. (1959). The theory and growth of the firm. New York: Oxford University Press.

Peteraf, M. A. (1993). The cornerstone of competitive advantage: A resource-based theory. Strategic Management Journal, 1(2), 179-191.

Pfeffer, J., \& Salancik, G. R. (1978). The external control of organizations: A resource dependence perspective. New York: Harper \& Row.

Poppo, L., \& Zenger, T. (2002). Do formal contracts and relational governance function as substitutes or complements? Strategic Management Journal, 23(8), 707-726.

Porter, M. E. (1991). Towards a dynamic theory of strategy. Strategic Management Journal, 12(S2), 95-117.

Rivera-Batiz, L. A., \& Romer, P. M. (1991). Economic integration and endogenous growth. Quarterly Journal of Economics, 106(2), 531-555.

Rugman, A., \& Verbeke, A. (2001). Subsidiary specific advantages in multinational enterprises. Strategic Management Journal, 22(2), 237-250.

Salomon, R., \& Jin, B. (2010). Do leading or lagging firms learn more from exporting? Strategic Management Journal, 31(10), 1088-1113. 
Schiele, H., Horn, P., \& Vos, B. (2011). Estimating cost-saving potential from international sourcing and other sourcing levers: Relative importance and trade-offs. International Journal of Physical Distribution and Logistics Management, 41, 315-336.

Schilling, J., \& Kluge, A. (2009). Barriers to organizational learning: An integration of theory and research. International Journal of Management Reviews, 11(3), 337-360.

Scott, W. R. (1995). Institutions and organizations. Thousand Oak, C.A.: Sage.

Shane, S., \& Venkataraman, S. (2000). The promise of entrepreneurship as a field of research. Academy of Management Review, 25(1), 217-226.

Shotter, A., \& Beamish, P. (2011). Performance effects of MNC headquarters-subsidiary conflict and the role of boundary spanners: The case of headquarter initiative rejection. Journal of International Management, 17(3), 243-259.

Skarmeas, D., \& Robson, M. J. (2008). Determinants of relationship quality in importer-exporter relationships. British Journal of Management, 19(2), 171-184.

Stuart, I., McCutcheon, D., Handfield, R., McLachlin, R., \& Samson, D. (2002). Effective case research in operations management: A process perspective. Journal of Operations Management, 20(5), 419-433.

Szulanski, G., Cappetta, R., \& Jensen, R. J. (2004). When and how trustworthiness matters: Knowledge transfer and the moderating effect of casual ambiguity. Organization Science, 15(5), 600-613.

Tallman, S., \& Chacar, A. (2011). Communities, alliances, networks and knowledge in multinational firms: A micro-analytic framework. Journal of International Management, 17(3), 201-210.

Tallman, S., \& Shenkar, O. (1994). A managerial decision model of international cooperative venture formation. Journal of International Business Studies, 25(1), 91-113.

Tan, J., Shao, Y., \& Li, W. (2013). To be different, or to be the same? An exploratory study of isomorphism in the cluster. Journal of Business Venturing, 28(1), 83-97.

Thorgren, S., Wincent, J., \& Håkan, B. (2012). Small firms in multipartner R\&D alliances: Gaining benefits by acquiescing. Journal of Engineering and Technology Management, 29(4), 453-467.

Verbeke, A., \& Yuan, W. (2007). Entrepreneurship in multinational enterprises: A penrosean perspective. Management International Review, 47(2), 241-258.

Williamson, O. E. (1991). Comparative economic organization: The analysis of discrete structural alternatives. Administrative Science Quarterly, 36(2), 269-296.

Wincent, J., Örtqvist, D., Eriksson, J., \& Autio, E. (2010). The more the merrier? The effect of group size on effectiveness in SME funding campaigns. Strategic Organization, 8(1), 43-68.

Wolff, J., \& Pett, T. (2006). Small-firm performance: Modeling the role of product and process improvements. Journal of Small Business Management, 44(2), 268-284.

Wright, M., Westhead, P., \& Ucbasaran, D. (2007). Internationalization of small and medium-sized enterprises (SMEs) and international entrepreneurship: A critique and policy implications. Regional Studies, 41(7), 1013-1029.

Yin, R. (2003). Case study research: Design and methods (3rd ed.). Thousand Oaks, C.A.: Sage Publication. 